\title{
The vagrant in the accident and emergency department
}

\author{
M. W. BECKETT \\ Accident and Emergency Department, Central Middlesex Hospital, London, England
}

\section{SUMMARY}

Those of no fixed abode constituted only $0 \cdot 3 \%$ of all new patients seen in one year. The majority presented with a disorder due to acute medical illness or trauma. This group has poor access to general practitioners, and turns to the accident and emergency department for medical care. However, the number of investigations performed and the number admitted to hospital indicate a substantial amount of serious pathology. The proportion of homeless attenders abusing the accident and emergency facilities is small.

\section{INTRODUCTION}

Homeless vagrants are commonly believed to be frequent visitors to the urban accident department. Unlikely to have a genuine complaint, their problems are seen as being mainly social rather than medical (Rutherford et al., 1980). They probably want no more than shelter and a cup of tea, and represent an unjustified demand on the resources of a busy department.

The purpose of this study was to enquire into the validity of this stereotype, to assess the workload due to those registering at an accident and emergency department as being of no fixed abode and to review the diagnoses made and treatment given to these patients.

\section{METHOD}

The Central Middlesex Hospital serves a partially industrial area with a large socially deprived population with many recent immigrants. The accident and emergency

Correspondence: Dr M. W. Beckett, Accident and Emergency Department, Central Middlesex Hospital, Acton Lane, Park Royal, London NW10 7NS 
department records for the 12 months from June 1983 to May 1984 were used tô identify all patients for whom no permanent address was recorded by the receptionis Excluded were all those too unwell to give any personal information, as well as tourist travelling salesmen and students.

\section{RESULTS}

A total of 117 patients were identified as being of 'no fixed abode'. Of these, 48 state\& that they were staying at the local Department of Health and Social Securit 9 Resettlement Unit. Only eight patients were women. The ages of the 117 patients are shown in Table 1. Most patients were either unemployed $(51 \mathrm{cases}$ ), or did not state्छ their employment (52 cases). It is likely that most of these had no regular employmen

Table 1

\begin{tabular}{lrr}
\hline Age & No. & $\%$ \\
\hline $0-19$ & 4 & 3 \\
$20-29$ & 30 & 26 \\
$30-39$ & 30 & 26 \\
$40-49$ & 18 & 15 \\
$50-59$ & 22 & 19 \\
$60+$ & 7 & 6 \\
Unknown & 6 & 5 \\
& 117 & 100 \\
\hline
\end{tabular}

Table 2 Distribution of attendances

\begin{tabular}{|c|c|c|c|c|c|}
\hline Month & No. & Day & No. & Time (hr) & $N \frac{\mathbb{Q}}{3}$ \\
\hline June & 10 & Monday & 16 & $0000-0400$ & 19 \\
\hline July & 5 & Tuesday & 10 & $0400-0800$ & 6 \\
\hline August & 9 & Wednesday & 9 & $0800-1200$ & 3 \\
\hline September & 11 & Thursday & 21 & $1200-1600$ & 1 敢 \\
\hline October & 11 & Friday & 17 & $1600-2000$ & $2 \xi$ \\
\hline November & 10 & Saturday & 19 & $2000-2400$ & 3P \\
\hline December & 4 & Sunday & 25 & & \\
\hline January & 8 & & & & $11 \%$ \\
\hline February & 11 & & 117 & & 1 \\
\hline March & 13 & & & & \\
\hline April & 17 & & & & \\
\hline \multirow[t]{2}{*}{ May } & 8 & & & & $\frac{0}{0}$ \\
\hline & 117 & & & & \\
\hline
\end{tabular}


Table 2 shows that there is little seasonal variation in the attendance rates. There is a concentration of patients attending in the latter half of the week, in spite of the high level of unemployment. The bulk of the attendances were between $8 \mathrm{a} . \mathrm{m}$. and midnight.

Forty cases (34\%) gave a history of non-acute disorder (present more than 24 hours without deterioration).

A total of 29 cases $(25 \%)$ gave the name of a local (West London) doctor as their general practitioner.

Many cases were trivial and did not require hospital facilities. As an indication of this, it was considered that at least 58 cases $(50 \%)$ could have been dealt with by a general practitioner-they were diagnosed by the casualty officer (senior house officer) without need of immediate investigation or specialist opinion, and did not require hospital facilities for treatment. However, a substantial proportion of all accident and emergency attenders present with minor conditions. For comparison the records of 100 consecutive attenders in March 1984 were examined and of these 39 were considered not to need hospital treatment.

Table 3

\begin{tabular}{|c|c|c|c|c|c|}
\hline Principal diagnosis & Total & X-rayed & $\begin{array}{l}\text { Other } \\
\text { tests }\end{array}$ & $\begin{array}{l}\text { Treated and } \\
\text { discharged }\end{array}$ & Admitted \\
\hline \multicolumn{6}{|l|}{ Refused to see } \\
\hline Social & 9 & & & & \\
\hline \multicolumn{6}{|l|}{ Trauma (including } \\
\hline 12 head injuries) & 34 & 19 & & 14 & 6 \\
\hline \multicolumn{6}{|l|}{ Medical (including } \\
\hline poisoning) & 43 & 17 & 9 & 15 & 15 \\
\hline Surgical & 5 & 2 & & 2 & 1 \\
\hline Psychiatric & 16 & 1 & & 3 & 2 \\
\hline ENT & 2 & & & 2 & \\
\hline \multirow[t]{2}{*}{ Dental (toothache) } & 1 & & & & \\
\hline & 117 & 39 & 9 & 36 & $23(20 \%)$ \\
\hline
\end{tabular}

Table 3 shows the diagnostic categories of the 117 patients, those $\mathrm{X}$-rayed, those discharged following treatment (including out-patient referral), and those admitted. During this period 42260 new patients were seen in the department, of whom approximately $8200(19 \%)$ were admitted to the wards.

\section{DISCUSSION}

The 117 patients of no fixed abode seen during one year represent $0.3 \%$ of all new patients seen by the accident and emergency department. Farmer \& Chambers (1982) in a survey of six London accident and emergency departments found that homeless 
attenders amounted to $0-1.4 \%$ of the total, with a mean of $0.7 \%$. Therefore, the workload represented by these patients is small.

It is perhaps surprising that there is no increase in the attendances in the winte months. This may be due to effective social welfare measures, or may in part be due to fewer people choosing to be homeless in the winter.

Clearly, a proportion of vagrants come to the accident and emergency department as they have no general practitioner. Half of all attendances required neither investigationo nor admission. Only $25 \%$ claimed to be registered with a local doctor, whereas a survey $\frac{\overline{\mathrm{O}}}{\overline{\mathrm{O}}}$. conducted in the Central Middlesex Hospital Accident and Emergency Department in 1981 (Lovell et al., 1983) estimated that between 97 and $99 \%$ of all attenders were registered. Hence, the department is providing a 'general practice' service to the homeless.

Most patients presented with acute medical or traumatic conditions and only $20 \%$ of consultations were for social or psychiatric causes. Investigation, usually radiological, was required in $40 \%$ and the proportion requiring admission to hospital $(20 \%)$ is as 3 great as among all accident and emergency attenders, including those referred byij general practitioners. These results demonstrate significant illness among the homeless $s_{\infty 0}^{N}$ commensurate with the increase in ill health associated with low social and economic status (Maclure \& Stewart, 1984).

For this mobile and often illiterate population, the accident and emergencyc department is often their only source of medical advice. It is therefore not surprising that they expect it to provide a 'general practitioner' service as well as access to hospital $\vec{\bullet}$ facilities. The homeless may sometimes receive little sympathy, but in fact, few of themo place unreasonable demands on the accident and emergency service.

\section{ACKNOWLEDGEMENTS}

I thank Mr S. S. Tachakra and Mr R. H. Coombs for advice and assistance, and Dr D. J. Shawe for constructive criticism.

\section{REFERENCES}

Farmer R. D. T. \& Chambers J. S. (1982) The relationship between the use of A \& E departments and theo availability of G.P. Services. Department of Community Medicine, Westminster Medical School.

Lovell A., Allsop J., Barron G. \& Tachakra S. (1983) An exploration of Non-Registration with Generato Practitioners in attenders at an Accident \& Emergency Department. Dept of Social Sciences, Polytechnic of the South Bank, London SE1.

Maclure A. \& Stewart G. T. (1984) Admission of children to hospitals in Glasgow: relationship to unemployment and other deprivation variables. Lancet ii, 682-5.

Rutherford W. H., Nelson P. G., Weston P. A. M. \& Wilson D. H. (1980) Accident and Emergency Medicine, p.4. London, Pitman. 